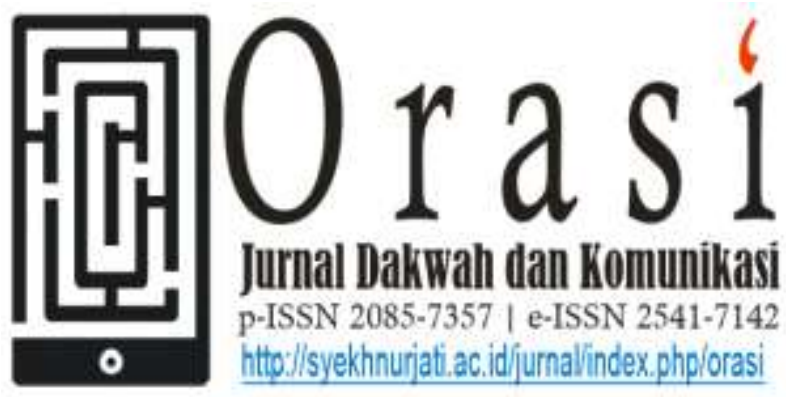

Volume 12 No. 1 Juli 2021

\title{
FRAMING MEDIA ONLINE TERHADAP KEBIJAKAN PENANGANAN PANDEMI COVID-19 DI INDONESIA
}

\section{ONLINE MEDIA FRAMING ON POLICIES FOR HANDLING THE COVID-19 PANDEMIC IN INDONESIA}

\author{
${ }^{1}$ Heppy N Y Haloho, ${ }^{2}$ Salman \\ Prodi Ilmu Komunikasi, Kalbis Institute, Jakarta \\ Jl. Jalan Pulomas Selatan Kav. 22, Jakarta Timur , DKI Jakarta 13210 , Indonesia \\ e-mail: ${ }^{1}$ Heppy.haloho@kalbis.ac.id \\ ${ }^{2}$ Salman.naning@kalbis.ac.id
}

\begin{abstract}
ABSTRAK
Penelitian ini secara khusus ditujukan untuk membongkar dan membandingkan framing dua media online nasional terkait kebijakan penanganan COVID-19 di Indonesia. Teori yang digunakan dalam riset ini adalah teori konstruksi realitas sosial media massa dari Peter L. Berger. Penelitian ini menggunakan pendekatan kualitatif dengan metode analisis isi. Data dalam penelitian ini diperoleh dari hasil dokumentasi berita di Kompas.com dan Tempo.co periode April - Mei 2020. Data kemudian dianalisis dengan menggunakan model analisis framing Robert Entman yang meliputi define problem, diagnosed caused, moral judgement dan treatment recommendaion. Hasil penelitian ini menemukan bahwa Kompas.com dan Tempo.co menggunakan bingkai yang berbeda dalam memberitakan kebijakan penanganan pandemic COVID-19 di Indonesia. Dalam bingkai Kompas.com, kebijakan penanganan COVID-19 di Indonesia belum efektif karena buruknya komunikasi publik pemerintah. Oleh sebab itu pemerintah diharapkan untuk segera memperbaiki komunikasi publiknya. Sedangkan dalam bingkai Tempo.co, ketidakefektifan kebijakan penanganan COVID-19 disebabkan oleh buruknya kinerja pemerintah dalam berbagai hal. Untuk itu pemerintah dituntut untuk melakukan evaluasi kinerja. Temuan ini menegaskan kembali bahwa framing media terhadap suatu isu/peristiwa sangat bergantung pada sudut pandang dan kepentingannya/keberpihakannya.
\end{abstract}

Kata Kunci: Berita, Framing, Kebijakan Penanganan Pandemi COVID-19, Media Online 


\begin{abstract}
This research is specifically aimed at dismantling and comparing the framing of two national online media related to the policies for handling the COVID-19 pandemic in Indonesia. The theory used in this research is the theory of social reality construction of mass media from Peter L. Berger. This study used a qualitative approach with content analysis as the method. The data were obtained from the news documentation on Kompas.com and Tempo.co for the period April May 2020. The data were then analyzed by using Robert Entman's framing analysis model which included define problems, diagnosed caused, moral judgment and treatment recommendations. The results of this study show that Kompas.com and Tempo.co used different frames in reporting policies on handling the COVID-19 pandemic in Indonesia. In the frame of Kompas.com, the policies for handling COVID-19 in Indonesia were not effective due to poor public communication by the government. Therefore, the government was expected to immediately improve their public communication strategies. Meanwhile, in the framework of Tempo.co, the ineffectiveness of policies in handling COVID-19 was caused by the government's poor performance in various matters. For this reason, the government was required to conduct a performance evaluation. These findings reaffirm that media framing of an issue/event highly depends on their point of view and interests/partisanship.
\end{abstract}

Keywords: COVID-19 Handling Policy, Framing, News, Online Media

\section{Pendahuluan}

Pandemi COVID-19 menuntut pemerintah di seluruh dunia tak terkecuali pemerintah di Indonesia untuk mengambil kebijakan yang tepat dalam waktu yang sangat singkat. Hal tersebut tentu saja tidak mudah untuk dilakukan. Banyak aspek yang harus ditimbang dengan cermat agar kebijakan yang dipilih dapat secara efektif menghentikan penyebaran virus dan menyelamatkan negara dari dampak kerugian akibat pandemi.

Sejak April - Mei 2020, sudah ada beberapa kebijakan penanganan COVID-19 yang dikeluarkan dan diterapkan oleh pemerintah. Namun demikian, pada awalnya lockdown adalah kebijakan yang ramai diperbincangkan oleh publik sejak masuknya COVID-19 di Indonesia. Para pejabat dan Publik figure tidak sedikit yang bersuara meminta pemerintah khususnya Presiden Jokowi untuk menerapkannya sebagaimana dilakukan oleh negara-negara lain yang juga terdampak pandemi.

Namun, pemerintah, khususnya Presiden Jokowi, menilai bahwa keputusan lockdown tidaklah tepat mengingat kondisi masyarakat Indonesia yang sangat berbeda dengan negara-negara yang menerapkan lockdown. Pemerintah justru lebih memilih kebijakan Pembatasan Sosial Berskala Besar (PSBB) untuk mencegah penyebaran COVID19 yang lebih luas di Indonesia (Pranita, Kompas.com, 2020).

Keputusan penerapan PSBB sempat menimbulkan pro dan kontra di masyarakat sehingga ramai diberitakan oleh media massa selama beberapa waktu. Dalam pemberitaan media, kebijakan lockdown versus PSBB dibingkai dan disajikan dari beragam sudut pandang. Misalnya saja portal berita online Tempo.co dan Kompas.com 
Dalam salah satu artikel beritanya yang berjudul, "Epidemiolog UI Paparkan Negara yang Tekan Corona dengan Lockdown" Tempo.co menyatakan bahwa lockdown adalah salah satu kebijakan yang layak untuk dipertimbangkan oleh pemerintah dalam menangani pandemi COVID-19 karena telah terbukti berhasil dilakukan oleh beberapa negara luar. Tempo.co bahkan menguatkan pernyataan tersebut dengan mengangkat seorang narasumber ahli yakni epidemolog dari Universitas Indonesia (Aji, Tempo.co, 2020). Hal ini secara tidak langsung menunjukkan posisi dukungan Tempo.co terhadap penerapan lockdown untuk menangani pandemi COVID-19 di Indonesia.

$$
\text { Berbeda dengan Tempo.co, }
$$

Kompas.com dalam beritanya yang berjudul, “

Indonesia tidak Pilih Lockdown sebagai solusi, Ini Alasannya" mengatakan bahwa meskipun ada negara-negara yang sukses dalam menerapkan kebijkan lockdown, ada juga negara seperti India yang dianggap gagal menerapkannya. Kompas.com bahkan menegaskan dalam beritanya bahwa Indonesia tidak selalu harus meniru kebijakan negara lain yang bisa jadi tidak sesuai dan tidak efektif dengan kondisi dan kultur masyarakat Indonesia (Pranita, Kompas.com, 2020). Hal ini secara tidak langsung menunjukkan bahwa Kompas.com lebih mendukung pemerintah dalam penerapan kebijakan PSBB dibandingkan lockdown untuk mengatasi penyebaran COVID-19.

Setelah kebijakan PSBB, kebijakan lain yang juga menimbulkan pro kontra di masyarakat adalah kebijakan new normal.
Terkait pro dan kontra tersebut, Tempo.co dan Kompas.com juga menunjukkan posisi dukungan yang berbeda. Hal ini tampak jelas dalam bingkai pemberitaan kedua media tersebut pada periode Mei 2020. Tempo.co dalam artikel beritanya yang berjudul, “Epidemolog Sebut Kebijakan New Normal masih Terlalu Dini" mengatakan bahwa penerapan new normal tidaklah tepat mengingat penularan virus korona masih belum terkendali (Hamdi, Tempo.co, 2020). Tempo.co juga konsisten menggunakan narasumber ahli yakni seorang epidemolog dari Universitas Indonesia untuk mendukung pandangannya tersebut. Selain itu dalam artikel beritanya yang lain, Tempo.co juga menggunakan narasumber elite, yakni Ketua Dewan Perwakilan Rakyat, Puan Mahariani, yang meminta pemerintah untuk tidak terburuburu dalam menyusun protokol new normal.

Berseberangan dengan Tempo.co, Kompas.com dalam artikel beritanya periode Mei 2020 justru lebih fokus untuk menyampaikan informasi tentang penerapan new normal dan kemungkinan tingkat keberhasilan/keefektifannya untuk mengurangi dampak pandemi di masyarakat. Dalam beritanya yang berjudul, "Indonesia menuju New Normal Corona, Ini Protokol Kesehatan Covid yang harus dilakukan" Kompas.co tampak tidak banyak menyoroti terkait kontra kebijakan ini, sehingga posisi dukungan Kompas.com terhadap kebijakan ini semakin terlihat jelas (Sumartiningtyas, Kompas.com, 2020). Kompas.com juga menggunakan frame positif untuk menjelaskan kemungkinan keberhasilan kebijakan new normal untuk 
memulihakan kondisi ekonomi masyarakat Indonesia. Selain itu narasumber yang dirujuk Kompas.com juga adalah dari pihak pemerintah yakni Presiden Jokowi. Tentu saja hal tersebut bisa kita maknai sebagai indikasi dukungan Kompas.com terhadap kebijakan new normal yang diinisiasi oleh pemerintah.

Perbedaan sudut pandang Tempo.co dan Kompas.com dalam memberitakan kebijakan penanganan pandemi COVID-19 (periode April- Mei 2020) sebenarnya tidak berhenti hanya pada persoalan kebijakan lockdown versus PSBB dan kebijakan new normal. Ada beberapa kebijakan COVID-19 lainnya yang juga dibingkai berbeda oleh kedua media berita online nasional ini. Misalnya kebijakan bantuan sosial COVID-19, larangan kerumuman dan penerapan prokes, keringanan kredit usaha, hingga kebijakan larangan mudik.

Perbedaan bingkai pemberitaan kedua media tersebut sebenarnya adalah hal yang lumrah terjadi. Media bagaimanapun adalah agen konstruksi yang memiliki sudut pandang dan kepentingannya masing-masing dalam memberitakan isu tertentu (Eriyanto, 2012: 25).

Sebagai agen konstruksi, media tidak dapat dilihat sebagai sarana yang netral karena ia juga adalah subjek yang mengkonstruksi realitas sehingga dimungkinkan adanya bias dalam prosesnya. Oleh sebab itu berita yang disajikan kepada pembaca bukan lagi hanya menggambarkan realitas dan pendapat dari sumber berita tetapi juga konstruksi dari media (wartawan/pembuat berita)(Eriyanto, 2012: 26)
Framing adalah salah satu cara yang umum digunakan oleh media massa untuk mengonstruksi realitas yang ada. Framing dilakukan dengan seleksi isu dan penonjolan isu tertentu (Eriyanto, 2012: 76).

Seleksi isu diartikan sebagai upaya media untuk memilih isu tertentu dari sebuah peristiwa yang dianggap menarik dan memiliki nilai berita. Proses seleksi isu menyebabkan adanya bagian dari sebuah isu/peristiwa yang disorot dan diberi ruang oleh media sementara bagian lainnya dihilangkan atau tidak ditampilkan. Dalam artian media menentukan bagaimana seharusnya kita memandang atau menilai sebuah realitas, dalam hal ini realitas kebijakan penanganan COVID-19 di Indonesia (Luhmann 2000, 78-79).

Sementara penonjolan berita dapat dimaknai sebagai salah satu upaya media dalam membingkai sebuah realitas dibenak pembaca dengan meletakannya pada bagian headline atau rubrik nasional untuk media online. Penempatan berita pada posisi ini akan membuat tingkat keterbacaannya menjadi semakin tinggi (Luhmann 2000, 78-79). Dalam konteks riset ini, kedua media secara umum menempatkan artikel beritanya pada kolom nasional yang paling sering muncul dan dibaca oleh khalayak.

Framing/pembingkaian media yang berbeda-beda dalam proses produksi berita pada dasarnya tidak dapat dihindari karena realitas memang sangat kompleks dan multi dimensi. Namun kecenderungan media untuk menggunakan satu frame secara konsisten dalam memberitakan satu isu bisa berdampak pada penggiringan opini Publik dalam 
mendefinisikan sebuah isu/peristiwa tanpa melihat dimensi lainnya.

Kebijakan penanganan COVID-19 adalah realitas yang kompleks yang tidak bisa dilihat dari satu atau dua sisi saja seperti baik atau buruk, pro atau kontra, efektif atau tidak efektif, tetapi juga harus dilihat dari banyak dimensi/aspek lainnya yang melekat dan berhubungan erat dengan isu yang diberitakan.

Oleh sebab penelitian ini kemudian ditujukan untuk mengetahui bagaimana media online (Tempo.co dan Kompas.com) membingkai kebijakan penanganan pandemic COVID-19 di Indonesia dalam pemberitaannya periode April 2020- Mei 2020.

Riset terkait framing media dalam memberitakan pandemic COVID-19 memang sudah pernah dilakukan sebelumnya. Peneliti menemukan dua riset terdahulu yang kemudian digunakan sebagai referensi dalam riset ini.

Riset pertama dilakukan oleh Ida Nuraini Dewi Kodrat Ningsi dan Narayana Mahendra Prastya dengan judul, "Bingkai Berita COVID-19 pada Praktek Jurnalisme Warga di Website Pemerintah". Riset ini bertujuan untuk mengetahui bingkai berita COVID-19 pada media jurnalisme warga, yakni Media Center Kabupaten Sleman, Yogyakarta. Hasil penelitian ini menemukan bahwa bingkai berita Covid 19 yang dibuat oleh warga (KIM Sleman) memuat topik-topik atau isu-isu yang memang berada dalam wilayah tinggal para warga. Hal ini terlihat dalam penuturan para penulis berita melalui topik-topik yang mereka paparkan dan keadaan sekitar tempat tinggal mereka.
Fenomena ini terjadi karena kedekatan antara penulis berita terhadap peristiwa yang terjadi (Ningsih \& Prastya, 2015).

Riset kedua adalah riset dari I Gusti Lanang Agung Kharisma Wibhisono yang berjudul, "Analisis Framing Pemberitaan COVID-19 pada koran Kompas: Edisi Januari 2020". Riset ini bertujuan untuk untuk menganalisis framing pemberitaan terkait COVID-19 pada periode 1 Januari 2020 - 30 Januari 2020 di Koran Kompas. Hasil riset ini menemukan bahwa pada awalnya surat kabar Kompas menyebut wabah virus corona adalah krisis regional. Oleh karena itu, pada periode sepertiga pertama (1-18 Januari 2020), surat kabar Kompas hanya membahas tentang merebaknya virus corona di Wuhan, China, dan beberapa negara lain seperti Hong Kong, Taiwan, Korea Selatan, dan Jepang. Pada periode ini, pemberitaan virus Corona juga tergolong langka karena Koran Kompas hanya memuat empat pemberitaan, yaitu informasi mengenai jumlah korban, gejala, dan kasus penyebaran di beberapa negara di luar Cina (Wibhisono, 2020)

Kedua penelitian rujukan yang digunakan berbeda dengan riset ini dalam hal tujuan, metode analisis dan media yang diteliti. Kesamaannya terletak pada tema yang diteliti yakni framing pemberitaan media terkait pandemi COVID-19.

\section{Metodologi Penelitian}

Paradigma yang digunakan sebagai landasan berpikir dalam penelitian ini adalah paradigma konstruktivisme. Paradigma ini 
berangkat dari teori konstruktivisme Immanuel Kant yang menyatakan bahwa pengetahuan adalah hasil konstruksi (Ronda 2018, 14). Hal ini berarti bahwa berita sebagai produk media massa adalah juga hasil konstruksi. Sementara para wartawan/pekerja media adalah agen yang mengembangkan makna-makna subjektif atas pengalaman-pengalaman mereka terkait realitas yang ada di sekitar kita (dalam konteks riset ini realitas kebijakan penanganan COVID-19).

Selanjutnya untuk mengetahui bagaimana media online membingkai kebijakan penanganan COVID-19 di Indonesia, peneliti menggunakan pendekatan kualitatif dengan metode analisi isi (teks media). Analisis isi kualitatif pada umumnya berupaya mengungkap makna di balik teks, simbol atau materi tekstual lainnya dengan menganalisis secara kritis berbagai kepentingan ataupun muatan nilai-nilai tertentu yang mendasari pembentukan teks maupun simbol-simbol tersebut (Martono 2015: 26). Yang berarti bahwa analisis isi kualitatif memandang bahwa segala macam produksi pesan seperti berita, iklan, sinetron, lagu dan symbol-simbol lainnya tidak lepas dari kepentingan-kepentingan dari si pembuat pesan (Kriyantono 2020, 206-208)

Menurut Payne and Payne; Scott \& Marshall metode analisis isi dapat digunakan untuk menginterpretasi teks dan simbol tertentu dan mengidentifikasi konsep semantik umum. Adapun yang menjadi tujuannya adalah untuk mengungkap makna/realitas di balik teks dan simbol tersebut. Sebab, sesungguhnya penggunaan atau pemilihan kata dalam suatu teks memiliki tujuan tertentu. Bahasa dapat menunjukkan kepentingan pihak tertentu maupun pandangan yang dianut. Bahkan menurut Bourdieu, bahasa adalah representasi kekuasan. Dengan demikian perlu disadari bahwa analisis isi bekerja secara eksplisit , terorganisir, terencana untuk menyusun data dan mengelompokkan, atau mengukur konsep yang diteliti, memeriksa pola dan hubungan mereka serta kemudian menafsirkannya (Martono 2015, 27).

Untuk mendapatkan data berupa teks berita di Tempo.co dan Kompas.com, peneliti menggunakan teknik dokumentasi manual menggunakan kata kunci. Kata kunci yang digunakan adalah kebijakan penanganan COVID-19, kebijakan pandemi, kebijakan psbb, kebijakan mudik selama pandemi dan kebijakan pemerintah tangani pandemi. Selain itu berita yang dipilih sebagai bahan riset dibatasi hanya untuk periode periode April - Mei 2020. Pemilihan periode tersebut disesuaikan dengan periode pemberitaan media yang mengangkat tentang kebijakan penanganan pandemi COVID-19 di Indonesia.

Berdasarkan hasil dokumentasi berita yang dilakukan terhadap kedua media, ditemukan 29 teks berita yang sesuai dengan tema riset ini. Tiga belas berita ditemukan di Tempo.co dan 16 berita di Kompas.com. 
Tabel 2.1. Berita di Tempo.co

\begin{tabular}{|c|}
\hline po.co \\
\hline Judul Berita \\
\hline $\begin{array}{l}\text { INDEF: Jokowi dan Menterinya Dapat } \\
\text { Rapor Merah Penanganan Corona } \\
\text { Minggu, } 26 \text { April } 2020 \text { 16:19 WIB }\end{array}$ \\
\hline $\begin{array}{l}\text { DPR Kritik Kebijakan Pemerintah } \\
\text { Tumpang Tindih Tangani COVID-19 } \\
\text { Rabu, } 29 \text { April } 2020 \text { 10:58 WIB }\end{array}$ \\
\hline $\begin{array}{l}\text { Peneliti Eijkman: Indonesia Belum Punya } \\
\text { Standar Kurva COVID-19 } \\
\text { Sabtu, } 9 \text { Mei } 2020 \text { 08:01 WIB }\end{array}$ \\
\hline $\begin{array}{l}\text { Jokowi Minta Pengendalian COVID-19 di } \\
\text { Pulau Jawa Makin Efektif } \\
\text { Selasa, } 12 \text { Mei } 2020 \text { 11:27 WIB }\end{array}$ \\
\hline $\begin{array}{l}\text { Politikus PDIP Minta Pemerintah Dengar } \\
\text { Tagar Indonesia Terserah } \\
\text { Kamis, } 21 \text { Mei } 2020 \text { 08:12 WIB }\end{array}$ \\
\hline $\begin{array}{l}\text { Penanganan COVID-19, Putri Gus Dur: } \\
\text { Era Milenial, Cara Kolonial } \\
\text { Senin, } 18 \text { Mei } 2020 \text { 08:01 WIB }\end{array}$ \\
\hline $\begin{array}{l}\text { Kebijakan Kontroversial Jokowi di Tengah } \\
\text { Pandemi } \text { COVID-19 } \\
\text { Senin, } 25 \text { Mei } 2020 \text { 08:03 WIB }\end{array}$ \\
\hline $\begin{array}{l}\text { Survei: Mayoritas Publik Tak Puas } \\
\text { Penanganan COVID-19 Pemerintah } \\
\text { Selasa, 26 Mei 2020 20:20 WIB }\end{array}$ \\
\hline $\begin{array}{l}\text { Ombudsman Sebut Kebijakan Pusat } \\
\text { Halangi Keberhasilan PSBB DKI (Kamis, } \\
28 \text { Mei } 2020 \text { 14:00 WIB) }\end{array}$ \\
\hline $\begin{array}{l}\text { JK Sebut Pemerintah Sia-siakan Golden } \\
\text { Time Penanganan COVID-19( Sabtu, } 23 \text { Mei } \\
2020 \text { 12:40 WIB) }\end{array}$ \\
\hline $\begin{array}{l}\text { Survei: Kerja Pemprov soal COVID-19 } \\
\text { Dinilai Lebih Baik dari Pusat } \\
\text { (Rabu, } 20 \text { Mei } 2020 \text { 03:04 WIB) }\end{array}$ \\
\hline $\begin{array}{l}\text { Potensi-potensi Penyimpangan } \\
\text { Penanganan Wabah COVID-19 Kata } \\
\text { ICW (Senin, } 18 \text { Mei } 2020 \text { 15:56 WIB) }\end{array}$ \\
\hline $\begin{array}{l}\text { Erick Thohir Sedih dengan Opini } \\
\text { Negatif Penanganan COVID-19 } \\
\text { (Jumat, } 29 \text { Mei } 2020 \text { 15:52 WIB) }\end{array}$ \\
\hline
\end{tabular}

(Sumber: Olahan Peneliti, 2020)
Tabel 2.2. Berita di Kompas.com

\begin{tabular}{|c|}
\hline \\
\hline Judul Berita \\
\hline $\begin{array}{l}\text { Pemerintah Diminta Perbaiki Komunikasi } \\
\text { Publik Terkait Kebijakan Penanganan } \\
\text { Pandemi(22/05/2020, 13:38 WIB) }\end{array}$ \\
\hline $\begin{array}{l}\text { Penanganan COVID-19, Pemerintah } \\
\text { Disarankan Gunakan Gaya Komunikasi } \\
\text { yang Mudah Diterima } \\
\text { (Senin }(18 / 5 / 2020) .)\end{array}$ \\
\hline $\begin{array}{l}\text { Penanganan COVID-19 Belum Optimal, } \\
\text { PSHK Minta Pemerintah Hati-hati } \\
\text { Terapkan "New Normal" }(27 / 05 / 2020)\end{array}$ \\
\hline $\begin{array}{l}\text { PKS: Pemerintah Membingungl } \\
\text { Salahkan Masyarakat Keliru M } \\
(19 / 05 / 2020,10: 32 \text { WIB })\end{array}$ \\
\hline $\begin{array}{l}\text { Pemerintah Diminta Perbaiki Komunikasi } \\
\text { soal Penanganan COVID-19, Ini Alasannya } \\
\text { Kompas.com }(22 / 05 / 2020,15: 12 \text { WIB })\end{array}$ \\
\hline $\begin{array}{l}\text { Ahli Psikologi Politik: Penanganan COVID- } \\
19 \text { di Indonesia Sama dengan Negara Lain, } \\
\text { tetapi...(10/05/2020) }\end{array}$ \\
\hline $\begin{array}{l}\text { Pemerintah Dinilai Inkonsisten Hadapi } \\
\text { COVID-19 }(7 / 5 / 2020) \text {. }\end{array}$ \\
\hline $\begin{array}{l}\text { ersial Pemerintah } \\
\text {, Apa Saja? } \\
\text { B) }\end{array}$ \\
\hline $\begin{array}{l}5 \text { Hal Ini dalam } \\
\text { OVID-19 }\end{array}$ \\
\hline $\begin{array}{l}\text { MUI Sebut Ada Pertentangan Sikap } \\
\text { Pemerintah dalam Penanganan COVID-19 } \\
(15 / 05 / 2020,20: 39 \text { WIB })\end{array}$ \\
\hline $\begin{array}{l}\text { nerintah dalam } \\
19 \\
\text { IB) }\end{array}$ \\
\hline $\begin{array}{l}\text { Pelaksanaan PSBB Dinilai Absurd, Banyak } \\
\text { Terjadi Penyimpangan Teknis (18/05/2020, } \\
\text { 15:59 WIB) }\end{array}$ \\
\hline $\begin{array}{l}\text { Masyarakat Abaikan PSBB, Akibat Tidak } \\
\text { Sinkronnya Kebijakan Pemerintah? } \\
(21 / 05 / 2020,08: 03 \text { WIB })\end{array}$ \\
\hline $\begin{array}{l}\text { "Indonesia Terserah", Kritik untuk } \\
\text { Pemerintah dan Pengingat untuk Kita } \\
\text { Semua... (17/05/2020, 09:46 WIB) }\end{array}$ \\
\hline $\begin{array}{l}\text { Riset Unpad-UP: } 86 \text { Persen Responden } \\
\text { Indonesia Dukung Larangan Mudik } \\
(22 / 05 / 2020,17: 04 \text { WIB })\end{array}$ \\
\hline $\begin{array}{l}\text { Berbagai Respons Rakyat untuk } \\
\text { Pemerintah Terkait Penanganan COVID } \\
(02 / 04 / 2020,10: 02 \text { WIB })\end{array}$ \\
\hline
\end{tabular}

(Sumber: Olahan peneliti, 2020)

Data inilah yang kemudian dianalisis menggunakan teknik analisis framing dari 
Robert Entman yang meliputi define problem, diagnose causes, make moral judgement, dan treatment recommendation.

Tabel 2.3. Perangkat Framing Robert Entman

\begin{tabular}{|l|l|}
\hline Perangkat Analisis & Penjelasan \\
\hline $\begin{array}{l}\text { Define Problems } \\
\text { (Pendefinisian } \\
\text { Masalah }\end{array}$ & $\begin{array}{l}\text { Bagaimana suatu } \\
\text { peristiwa/isu dilihat? } \\
\text { Sebagai apa? Atau } \\
\text { sebagai masalah apa? }\end{array}$ \\
\hline $\begin{array}{l}\text { Diagnose Causes } \\
\text { (memperkirakan } \\
\text { masalah atau sumber } \\
\text { masalah) }\end{array}$ & $\begin{array}{l}\text { Peristiwa itu dilihat } \\
\text { disebabkan oleh apa? } \\
\text { Apa yang dianggap } \\
\text { sebagai penyebab } \\
\text { dari suatu masalah? } \\
\text { Siapa (aktor) yang } \\
\text { dianggap sebagai } \\
\text { penyebab masalah? }\end{array}$ \\
\hline $\begin{array}{l}\text { Make Moral } \\
\text { Judgement } \text { (membuat } \\
\text { keputusan Moral }\end{array}$ & $\begin{array}{l}\text { Nilai moral apa yang } \\
\text { disajikan untuk } \\
\text { menjelaskan } \\
\text { masalah? Nilai } \\
\text { Moral apa yang } \\
\text { dipakai untuk } \\
\text { melegitimasi atau } \\
\text { mendeligitimasi } \\
\text { suatu tindakan. }\end{array}$ \\
\hline $\begin{array}{l}\text { Penyelesaian apa } \\
\text { yang ditawarkan } \\
\text { untuk mengatasi } \\
\text { masalah/isu? Jalan } \\
\text { apa yang ditawrkan } \\
\text { dan harus ditempuh } \\
\text { untuk mengatasi } \\
\text { masalah? }\end{array}$ \\
\hline $\begin{array}{l}\text { Recomentation } \\
\text { penyelesaian) }\end{array}$
\end{tabular}

(Sumber: Eriyanto, 2012, 223)

Perangkat inilah yang akan digunakan untuk menganalisis setiap berita kebijakan penanganan COVID-19 di Tempo.co dan Kompas.com untuk mengetahui framing yang digunakan.

\section{Hasil dan Pembahasan}

\subsection{Hasil}

Berdasarkan pengumpulan data berita di Kompas.com dan Tempo.co periode April -
Mei 2020, terdapat 29 berita terkait kebijakan penanganan COVID-19 yang akan dianalisis dalam riset ini. Data tersebut terdiri dari 16 berita di Kompas.com dan 13 berita di Tempo.co. Berikut ini adalah hasil analisis untuk masing-masing media dengan menggunakan teknik analisis framing Robert Entman:

\subsubsection{Frame Kompas.com}

Portal media online Kompas.com mulai ramai memberitakan kebijakan penanganan COVID-19 sejak akhir Maret 2020. Namun demikian hingga pertengah April 2020, bingkai pemberitaan Kompas.com secara umum lebih terfokus pada pemaparan/penjelasan setiap kebijakan pemerintah untuk menangani penyebaran virus hingga kebijakan dalam menangani/ mengantisipasi dampak pandemi. Kompas.com baru mulai menyoroti terkait efektivitas dan permasalahan dalam kebijakan penanganan COVID-19 oleh pemerintah pada akhir April Mei 2020.

\section{a. Define Problem}

Kompas.com mengidentifikasi tidak efektifnya kebijakan penanganan COVID-19 sebagai masalah komunikasi. Segala hal yang berhubungan dengan tidak efektifnya kebijakan penanganan COVID-19 di Indonesia dinilai terjadi karena buruknya komunikasi Publik pemerintah kepada masyarakat. Ada beberapa alasan mengapa kita dapat mengatakan bahwa komunikasi adalah bingkai yang dominan dalam pemberitaan Kompas.com terkait efektivitas penanganan COVID-19. 
Pertama, semua masalah yang menyebabkan tidak efektifnya pelaksanaan kebijakan yang diambil oleh pemerintah ditarik ke dalam persoalan komunikasi. Komunikasi publik pemerintah dinilai masih perlu diperbaiki karena belum bisa menyesuaikan dengan tingkat sumber daya (SDM) dan budaya masyarakat. Informasi tentang kebijakan penanganan COVID-19 yang disampaikan pemerintah dinilai tidak bisa dipahami karena bahasa yang digunakan tidak mudah dipahami publik. Selain itu masyarakat juga dinilai kebingungan karena adanya tumpang tindih kebijakan antara pusat dan daerah dalam hal penanganan COVID-19. Buruknya komunikasi publik pemerintah menurut Kompas.com adalah persoalan utama yang mengakibatkan tidak efektifnya kebijkan penanganan COVID-19 di Indonesia. Berita yang simpang siur dan keliru serta cenderung menakut-nakuti dinilai membuat masyarakat panik dan paranoid. Apalagi dengan tidak adanya kejelasan data pasien COVID-19, kecemasan masyarakat dinilai wajar meningkat karena banyaknya hoax, rumor dan konspirasi yang berdar.

Kedua, Kompas.com beberapa kali mengangkat akademisi dan praktisi dari bidang komunikasi sebagai narasumbernya yakni Dekan Fakultas Ilmu Komunikasi Universitas Padjadjaran, Dadang Rahmat Hidayat dan Praktisi komunikasi dan pembawa acara Helmy Yahya. Pernyataan dari akademisi Dadang Rahmat Hidayat bahkan dimuat dalam dua artikel berita sekaligus. Dengan menjadikan kedua tokoh ini sebagai narasumber utama secara tidak langsung kita dapat melihat bahwa bagi Kompas.com, tidak efektifnya penanganan COVID-19 adalah disebabkan oleh buruknya komunikasi publik dari pemerintah.

\section{b. Diagnose causes}

Dalam hampir keseluruhan berita Kompas.com, pemerintah diposisikan sebagai pelaku (aktor) yang menyebabkan masalah. Pemerintah yang dimaksud dalam hal ini adalah pemerintah pusat dan pemerintah daerah. Keduannya ditempatkan sebagai penyebab tidak efektifnya kebijakan penanganan COVID-19 di Indonesia. Dalam artian masalah penanganan COVID-19 pada umumnya bersumber dari pihak pemerintah bukan dari masyarakat yang menjadi sasaran kebijakan.

Dalam salah satu beritanya yang berjudul, "PKS: Pemerintah Membingungkan, Jangan Salahkan Masyarakat Keliru Memahami", Kompas.com menegaskan bahwa masyarakat tidak dapat disalahkan karena pemerintahlah penyebab dari permasalahan penanganan COVID-19 yang dianggap tidak berhasil. Oleh karena ditempatkan sebagai penyebab masalah maka berita Kompas.com secara keseluruhan menjelaskan bahwa masyarakat adalah korban. Tidak hanya itu, hampir keseluruhan berita pada periode AprilMei 2020 lebih banyak menyoroti kekurangan pemerintah mulai dari buruknya komunikasi Publik, inkonsistensi kebijakan hingga ketidaktegasan pemerintah dalam menerapkan aturan yang telah ditetapkan.

“..Contoh tadi bukan kali pertama pemerintah terkesan inkonsisten. Mengambil satu contoh lain, seperti beda aturan antarkementerian, soal 
boleh atau tidaknya ojek online mengangkut penumpang saat PSBB.

"Hampir semua protap dalam menangani COVID-19 adalah protap yang inkonsisten," ujar pakar kebijakan publik dan ekonomi Ichsanuddin"(Kompas.com)

Dari pernyataan tersebut tampak bagaimana Kompas.com menilai bahwa pemerintah adalah aktor utama penyebab tidak efektifnya berbagai kebijakan penanganan COVID-19 di Indonesia. Isi artikel tersebut memang membahas terkait persoalan inkonsistensi kebijakan pemerintah, namun tentu saja kita tidak dapat memisahkannya dari persoalan komunikasi yang tidak terintegrasi antara pemerintah pusat dan pemerintah daerah dalam menangani COVID-19.

Meskipun dalam beberapa beritanya, Kompas.com berupaya untuk menunjukkan bahwa masyarakat juga berkontribusi dalam menentukan tingkat keberhasilan kebijakan yang diambil, namun porsi permberitaan untuk hal tersebut tidaklah sebanyak porsi pemberitaan terkait evaluasi kebijakan Pemerintah. Kompas.com bahkan menghadirkan narasumber ahli yakni pakar Kebijakan Publik dan Ekonomi, Ichsanuddin, untuk menegaskan penilainnya tersebut.

Dalam pemberitaan Kompas.com, selain tidak konsisten, pemerintah juga dinilai membuat kebijakan tidak berbasis pada pengenalan masalah secara benar. Hal inilah yang menyebabkan tidak efektifnya kebijakan yang diambil. Belum lagi kebijakan tersebut juga tidak dikomunikasikan dengan baik, akibatnya tentu menjadi semakin buruk. Dengan menempatkan Pemerintah sebagai penyebab masalah, maka fokus pemberitaan Kompas.com secara keseluruhan adalah memberikan masukan yang dinilai dapat membantu pemerintah untuk meningkatkan tingkat keberhasilan kebijakan yang telah ditetapkan. Hal ini tampak jelas dalam keseluruhan artikel beritanya yang pada umumnya mendorong pemerintah untuk mengoptimalkan penerapan kebijakan yang ada.

\section{c. Moral judgement}

Penilaian terhadap pemerintah sebagai sumber masalah tidak efektifnya kebijakan penanganan COVID-19 bersumber dari penilaian moral yang dikenakan kepada pemerintah. Penilaian moral yang pertama adalah terkait lemahnya kemampuan pemerintah dalam mengkomunikasikan krisis kepada Publik (kurangnya kredibilitas pembicara maupun kredibilitas informasi yang disampaikan). Yang kedua adalah kurangnya kordinasi pemerintah pusat dan daerah dalam menjalankan kebijakan yang sudah ditetapkan. Hal ini berdampak pada aturan dan infromasi yang tidak konsisten dan cenderung berubahubah.

Pemerintah juga dinyatakan tidak berhati-hati dalam menyampaikan informasi ke masyarakat sehingga menimbulkan kecemasan dan ketakutan yang berlebihan. Penerapan kebijakan New Normal misalnya. Dalam pemberitaan Kompas.com penetapan kebijakan new normal yang direncanakan pemerintah di tengah masih tingginya kasus COVID-19 adalah indikator bahwa pemerintah lebih fokus pada kepentingan ekonomi dibandingkan keselamatan masyarakat. Hal ini 
membuat itikad baik pemerintah dalam penanganan COVID-19 menjadi perlu dipertanyakan.

"Fajri pun mempertanyakan iktikad baik pemerintah dalam persiapan menuju new normal. Menurutnya, saat ini kurva kasus penularan COVID-19 belum juga melandai, bahkan kasus kematian masih terus bertambah. Ia kembali mengingatkan bahwa setiap pengambilan kebijakan yang dilakukan pemerintah mesti berdasarkan pada perlindungan hak asasi manusia (HAM)."(Kompas.com)

Kompas.com juga mengutip pernyataan dari Gabriel Lele, Dosen Manajemen Kebijakan Publik (MKP) Universitas Gadjah Mada (UGM) Yogyakarta, yang menyatakan bahwa secara makro, Indonesia tidak memiliki risk governance yang jelas dalam seluruh lapis pemerintahan. Hal inilah yang berdampak pada ketidakmampuan pemerintah pusat dan daerah untuk bersinergi dalam menyusun komunikasi krisis yang baik. Pemerintah pusat dan daerah juga terfragmentasi secara otoritas akibat otonomi sehingga pengambilan kebijakan cenderung tumpang tindih atau bahkan bertentangan satu dengan yang lain.

\section{d. Treatment recommendation}

Untuk mengatasi persoalan tidak efektifnya kebijakan penanganan COVID-19, Kompas.com menyarakan pemerintah untuk memperbaiki komunikasi publiknya. Perbaikan dapat dilakukan dengan cara menggunakan komunikator yang kredibel, memakai bahasa yang mudah dipahami, menyampaikan informasi yang jelas, akurat dan transparan kepada Publik.

Pemerintah pusat dan pemerintah daerah juga diharapkan dapat saling berkoordinasi dalam pengambilan kebijakan agar tidak terjadi tumpang tindih kebijakan yang bisa membuat masyarakat bingung dalam memahami kebijakan yang diambil. Selain itu, Kompas.com juga menyarankan agar pemerintah dalam menyusun regulasi maupun aturan harus selalu berbasis pada data ilmiah bukan data sekelompok orang yang pada akhirnya menghasilkan kebijakan yang menguntungkan sekelompok orang pula.

\subsubsection{Frame Tempo.co}

Portal berita Tempo.co mulai memberitakan terkait efektifitas kebijakan penanganan COVID-19 di Indonesia sejak 26 April 2020. Namun frekuensi pemberitaan pada akhir April tidaklah sebayak pemberitaan Tempo.co pada bulan Mei. Tercatat ada 11 berita Tempo.co yang menyoroti terkait tidak efektifnya kebijakan penanganan COVID-19 di Indonesia pada bulan Mei dan 2 berita di bulan April 2020. Berikut ini adalah analisis terhadap 13 berita Tempo.co berdasarkan perangkat analisis Framing dari Robert Entman:

\section{a. Define Problem}

Teтpo.co mengidentifikasi permasalahan tidak efektifnya kebijakan penanganan COVID-19 di Indonesia bukan semata-mata sebagai persoalan komunikasi pemerintah yang buruk tetapi persoalan kinerja pemerintah yang buruk. Ada beberapa hal yang bisa membuktikan mengapa Tempo.co melihat isu ini sebagai permasalahan buruknya kinerja pemerintah.

Pertama, dalam pemberitaannya pada akhir April 2020, Tempo.co mengangkat hasil 
riset tentang sentiment negatif masyarakat terhadap pemerintah. Hasil riset ini menyatakan bahwa kebijakan penanganan COVID-19 adalah salah satu penyebab munculnya sentimen negatif terhadap pemerintah. Secara tidak langsung kita bisa memahami bahwa kinerja pemerintah dalam menangani COVID-19 tidak mendapatkan respon positif dari masyarkat.

Kedua, dalam pandangan Tempo.co, pemerintah pusat tidak saja gagal dalam berkoordinasi dengan semua stakeholders tetapi juga tidak mampu bersinergi dengan pemerintah daerah. Tempo.co mengutip pernyataan Syahrul, Anggota Komisi V Dewan Perwakilan Rakyat dari Fraksi PKS yang menyebutkan bahwa ada empat stakeholder yang saling berkaitan dalam menangani COVID-19 yakni Kementerian Keuangan, Kementerian Dalam Negeri, Kementerian Desa PDTT, dan Kementerian Sosial. Namun demikian pemerintah pusat dianggap tidak mampu mengintegrasikan keempat kementerian ini dalam menangani COVID-19 sehingga terjadi tumpang tindih aturan dan kebijakan.

Ketiga, Tempo.co juga menyoroti cara pemerintah (pusat) dalam pemberian bantuan bagi mereka yang terdampak pandemic. Menurut Tempo.co, pemerintah terlalu kaku dan tidak fleksibel dalam menetapkan aturan birokrasi yang sebenarnya bisa disederhanakan mengingat situasi saat ini. Tempo.co memandang bahwa pemerintah seharusnya tidak terkungkung dengan kriteria kemiskinan yang dipakai dalam keadaan normal. Tempo.co mengutip pernyataan -
Presidium Masyarakat Anti Fitnah Indonesia (MAFINDO) Anita Wahid yang menyatakan bahwa penanganan pandemic oleh pemerintah mirip jaman kolonial karena tidak fokus pada hasil. Selain itu pemerintah juga dinilai tidak inovatif dalam pengendalian COVID-19.

Keempat, Tempo.co juga mengkritik kinerja pemerintah dalam menyajikan data kurva COVID-19 yang belum juga ada setelah 68 hari virus ini masuk ke Indonesia. Padahal menurut keterangan peneliti dari EijkmanOxford Clinical Research Unit (EOCRU), Iqbal Elyazar yang dikutip oleh Tempo.co, kurva ini dapat digunakan sebagai salah satu cara menilai pelaksanaan kebijakan pengendalian COVID-19.

Berdasarkan 4 alasan tersebut secara tidak langsung kita dapat melihat kearah mana Tempo.co ingin menarik kasus ini. Dalam salah satu artikel beritanya, Tempo.co bahkan mengutip pernyataan Syahrul yang mengatakan bahwa penanganan pandemi tidak terlalu sulit asalkan arah dan jalur koordinasinya bagus. Namun buruknya kinerja pemerintah pusat dalam berbagai hal menyebabkan banyaknya korban yang berjatuhan akibat pandemi ini.

\section{b. Diagnose causes}

Dalam keseluruhan berita Tempo.co, Pemerintah Pusat khususnya Presiden Jokowi ditempatkan/diposisikan sebagai pelaku (aktor) di balik tidak efektifnya kebijakan penanganan COVID-19 di Indonesia. Tempo.co memandang bahwa kebijkaan kontroversial yang diambil oleh Jokowi adalah salah satu penyebab tidak efektifnya pengendalian COVID-19 di Indonesia. 
Tempo.co menguatkan pandangan tersebut dengan melaporkan hasil survei Indobarometer bekerja sama dengan Radio Republik Indonesia (RRI) tentang kepuasan masyarakat terhadap kinerja pemerintah dalam penanganan Covid-19. Hasil survey tersebut menunjukkan bahwa sebagian masyarakat menyatakan tidak puas dengan dengan cara pemerintahan Presiden Jokowi dan Wakil Presiden Ma'ruf Amin dalam menangani pandemi Covid-19. Survei ini menemukan bahwa 53,8 persen responden menilai tidak puas.

Selain itu Tempo.co juga membandingkan kinerja Pemerintah pusat dengan kinerja pemerintah Provinsi dalam penanganan COVID-19. Tempo.co melaporakan hasil survei dari Roda Tiga Konsultan (RTK) yang menunjukkan bahwa pemerintah provinsi jauh lebih baik kinerjanya dibandingkan dengan pemerintah pusat. Bahkan dari keseluruhan tingkatan pemerintahan, Tempo.co menyatakan bahwa pemerintah pusat memiliki kinerja paling rendah.

Tempo.co juga menguatkan asumsi buruknya kinerja pemerintah pusat dalam menangani Covid-19 dengan memberitakan tagar \#Indonesiaterserah yang awalnya muncul sebagai reaksi kekecewaan para pekerja medis terhadap masyarakat yang tidak mematuhi protokol kesehatan. Namun oleh Tempo.co tagar tersebut dimaknai lebih luas sebagai peringatan bahwa kepercayaan publik bisa hilang terhadap pemerintah bila tetap mengabaikan fakta yang terjadi selama pandemi Covid-19. Hal ini semakin menguatkan pandangan Tempo.co bahwa Pemerintah Pusat-lah penyebab masalah yang mengakibatkan tidak efektifnya penanganan COVID-19 di Indonesia.

\section{c. Moral judgement}

Penilaian Tempo.com atas pemerintah pusat khususnya Jokowi sebagai penyebab masalah bersumber dari beberapa penilaian negatif terhadap kebijakan penanganan COVID-19 dari pemerintah pusat. Pertama, Pemerintah Pusat khususnya Jokowi dinilai tidak jujur (bohong) dan tidak terbuka dalam menyampaikan data kurva COVID-19 sehingga klaim terkait perlambatan kurva Covid-19 bisa dikatakan meragukan. Pemerintah juga tidak punya bukti ilmiah untuk membuktikan keberhasilan PSBB.

Kedua, pemerintah pusat dinilai tidak menghargai perjuangan tenaga medis dan setiap orang yang menahan diri di rumah untuk mengendalikan penyebaran COVID-19. Hal ini terjadi setelah adanya inkonsistensi pemerintah dalam menerapkan kebijakan penanganan COVID-19. Hal ini terbukti dari viralnya sebuah video yang menggambarkan kerumunan orang-orang yang antri pulang kampung di Bandara Soekarno Hatta pada masa Pembatasan Sosial Berskala Besar diterapkan.

Ketiga, pemerintah dinilai telah kehilangan empati karena menaikkan iuran Iuran kelas III akan naik menjadi Rp 35 ribu di tengah pandemi. Tempo.co melaporkan bahwa ada lebih dari 12 ribu orang menandatangani 
petisi menolak kenaikan iuran BPJS melalui laman Change.org.

Keempat, pemerintah menurut padangan Tempo.co dinilai lamban dalam menangani pandemi COVID-19. Tempo.co dalam salah satu artikel beritanya mengutip pernyataan Yusuf Kalla yang menyatakan bahwa kecepatan adalah faktor utama dalam menentukan keberhasilan penanganan bencana. Menurut Tempo.co, isu virus COVID-19 sudah kita dengar dari JanuariFebruari, namun pemerintah tetap tidak tanggap dan cenderung menganggap sepele hal tersebut.

\section{d. Treatment recommendation.}

Atas semua hal yang menyebabkan tidak efektifnya kebijakan penanganan COVID-19 di Indoensia, Tempo.co menyarankan pemerintah untuk melakukan dua hal. Pertama, pemerintah pusat diharapkan untuk mengevaluasi cara kerja dalam menangani COVID-19. Misalnya dengan melakukan sinkronisasi kebijakan dan penyederhanaan birokrasi untuk memutus mata rantai COVID-19.

Kedua, Tempo.co menyarakankan agar pemerintah mengeluarkan kurva epidemologis sesuai standar ilmu Epidemologi. Selain itu pemerintah harus menyampaikan data jumlah pemeriksaan PCR (polymerase chain reaction) secara terbuka dan transparan kepada publik untuk meningkatkan kepercayaan publik terhadap pemerintah.

Ketiga, pemerintah disarankan untuk mendengarkan suara publik dan tidak mengabaikan fakta-fakta di lapangan dalam merumuskan kebijakan penanganan COVID19. Hal ini ditujukan untuk menghindari pengambilan kebijakan yang salah dan justru menyulitkan masyarakat di tengah situasi pandemi.

\subsection{Pembahasan}

Berdasarkan hasil analisis dari semua artikel berita baik di Kompas.com dan Tempo.co (periode 26 April 2020 -30 Mei 2020) dengan menggunakan perangkat Framing Robert Entman, peneliti menemukan bahwa keduanya menggunakan frame berita yang berbeda dalam memberitakan tentang kebijakan penanganan Covid-19. Sebagaimana dikatakan oleh Robert Entman (Eriyanto, 2012: 76) terkait dimensi framing, yakni seleksi isu dan penekanan isu, kedua media inipun melakukan dua langkah tersebut. Namun demikian seleksi dan penonjolan isu yang dilakukan oleh kedua media online ini tidaklah sama.

Perbedaan seleksi isu dan penekanan isu dalam bingkai berita Kompas.com dan Tempo.co tampak jelas dalam keempat kategori perangkat framing Robert Entman yakni pendefinisian masalah, diagnosa sumber masalah, pembuatan keputusan moral hinggga penekanan penyelesaian masalah. Tidak hanya itu, perbedaan penekanan isu juga terjadi dalam pemberitaan kedua media ini. Kompas.com cenderung menaruh berita terkait kebijakan Covid-19 di rubric nasional dan rubric trend. Sedangkan Tempo.co menaruh beritanya pada rubrik nasional dan bisnis. 
Selain itu perbedaan bingkai pemberitaan kedua media online nasional ini juga tampak dalam hal pemilihan narasumber beritanya. Kompas.com cenderung mengangkat narasumber yang beragam latarbelakangnya dibandingkan dengan Tempo.co. Hal ini jelas menunjukkan keberpihakan kedua media ini dalam menanggapi kebijakan penanganan Covid-19 oleh pemerintah. Sudut pandang Kompas.com dalam memberitakan kebijakan pemerintah dalam penanganan COVID-19 cenderung lebih netral dibadingkan dengan Tempo.co. Hal ini tampak dari isi berita Kompas.com yang beberapa kali terkesan turut mendukung kebijakan pemerintah dengan cara memberi penjelasan terkait setiap kebijakan yang diambil. Namun demikian Kompas.com juga tetap aktif memberikan kritik terhadap berbagai kekurangan dalam pelaksanaan kebijakan yang ditetapkan oleh pemerintah. Berbeda dengan Kompas.com, Tempo.co dalam semua pemberitaannya tampak jelas menunjukkan tidak berpihak pada pemerintah dalam hal kebijakan penanganan COVID-19. Tidak heran bila pemeberitaannya selalu dikaitkan dengan kinerja buruk pemerintah. Berikut ini adalah temuan peneliti terkait perbedaan frame yang digunakan oleh Kompas.com dan Tempo.co:

Dalam hal pendefinisian masalah, Kompas.com dan Tempo.co memiliki sudut pandang yang berbeda. Kompas.com cenderung melihat bahwa kebijakan penanganan Covid-19 adalah persoalan komunikasi. Persoalan komunikasi yang dimaksud bukan saja persoalan komunikasi pemerintah dengan publik tetapi juga komunikasi antar stakeholder di pemerintahan dalam proses penerapan kebijakan covid-19. Selain itu, persoalan komunikasi dalam kebijakan penanganan Covid-19 juga meliputi penggunaan bahasa dan pembicara yang tepat agar informasi dapat diterima dan dipahami oleh masyarakat yang beragam latarbelakangnya. Hal ini sangat berbeda dengan sudut pandang Tempo.co yang dalam keseluruhan pemberitaannya konsisten menggunakan bingkai kinerja buruk pemerintah dalam penanganan Covid-19 di Indonesia. Tempo.co menjadikan komunikasi sebagai akar masalah tidak efektifnya penanganan Covid-19 di Indonesia.

Baik Kompas.com dan Tempo.co sama-sama memiliki argumen yang kuat dalam mendukung sudut pandangnya. Kompas.com mengangkat narasumber dari kalangan akademisi yang dianggap kredibel dalam menilai persoalan kebijakan penanganan Covid-19 di Indonesia. Kompas.com juga mendukung pendapat para akademisi dan praktisi komunikasi yang menyebutkan bahwa komunikasi publik dan komunikasi krisis pemerintah adalah penyebab utama tidak efektifnya penanganan Covid-19 di Indonesia. Menurut Kompas.com, kesimpang-siuran informasi dan tumpang tindih kebijakan pemerintah berakar dari persoalan komunikasi pemerintah yang belum baik.

Berbeda dengan Kompas.com, Tempo.co menguatkan argumennya terkait kinerja buruk pemerintah dengan melaporkan beberapa hasil survey tingkat kepuasan Publik 
terhadap kinerja pemerintah. Tempo.co bahkan mendukung lembaga INDEF yang memberi kartu merah untuk Jokowi dan menterinya dalam menangani Covid-19.

Untuk mendukung frame buruknya kinerja pemerintah dalam penanganan Covid19, Tempo juga menghadirkan hasil survey yang membandingkan kinerja pemerintah pusat, provinsi dan daerah dalam pemberitaannya. Hasil riset tersebut menunjukkan bahwa pemerintah pusat mendapatkan respon paling tidak memuaskan dari masyarakat. Tempo.com bahkan berpendapat bahwa kinerja pemerintah provinsi jauh lebih baik dari Pemerintah pusat. Menarikanya, Kompas.com yang juga mengambil data dari lembaga survey yang sama tidak menyatakan demikian. Dalam pemberitaan Kompas.com, kinerja ke-tiga lapisan pemerintahan dalam menangani Covid19 dinilai relatif sama, yaitu sama-sama sedang-sedang saja dan tidak istimewa

Frame kinerja buruk pemerintah pusat dalam penanganan Covid-19 ini menunjukkan bahwa dalam sudut pandang Tempo.co, pemerintah pusatlah yang menyebabkan ketidakefektifan penanganan covid-19 di Indonesia. Lebih jauh lagi, dalam salah satu artikel beritanya yang berjudul, "Penanganan Covid-19, Putri Gus Dur: Era Milenial, Cara Kolonial", Tempo.co menilai bahwa penanganan Covid-19 oleh pemerintah pusat saat ini tidak tepat karena masih menggunakan cara kolonial yang cederung kaku dan tidak inovatif.

"Menurut Anita Wahid, karena tidak fokus pada hasil, cara kerja pemerintah menjadi tidak inovatif. Ia menyebut, pemerintah menangani masalah yang terjadi di era milenial dengan cara kolonial.Anita Wahid mencontohkan cara kerja yang inovatif dilakukan pemerintah Kabupaten Banyuwangi. Bupati Banyuwangi Abdullah Azwar Anas yang langsung turun ke masyarakat untuk mengatasi masalah pendataan bantuan sosial alias bansos" (Tempo.co)

Selain memberikan kritik terhadap kebijakan pemerintah dalam menangani Covid-19, Tempo.co juga mencurigai adanya potensi penyimpangan (menciptakan potensi korupsi) yang muncul dari situasi pandemic akibat lemahnya institusi publik. Sementara menurut Kompas.com penyimpangan yang mungkin terjadi dalam kebijakan Covid-19 adalah penyimpangan teknis dalam penerapan PSBB bukan penyimpangan korupsi anggaran maupun monopoli pengadaan alat kesehatan sebagaimana yang diberitakan oleh Tempo.co. Kompas.com sama sekali tidak mencurigai akan adanya penyimpangan dana penanganan COVID-19. Hal ini menunjukkan bahwa Kompas.com masih menilai positif upaya pemerintah sedangkan Tempo.co terkesan tidak mempercayai upaya pemerintah.

Adanya perbedaan definisi masalah yang digunakan oleh kedua media ini merupakan implikasi dari adanya perbedaan sudut pandang (ideologi) dan keberpihakan dari kedua media. Kompas.com dalam pemberitaannya tampak berusaha untuk memberikan penilaian yang objektif terhadap kebijakan pemerintah. Kompas.com memang mengkritik pemerintah yang buruk komunikasi dan koordinasinya, tetapi di saat yang sama 
Kompas.com juga mengingatkan masyarakat agar disiplin dalam menerapkan protokol kesehatan. Kompas.com bahkan menilai bahwa kunci keberhasilan penanganan Covid-19 adalah koordinasi antara pemerintah dan masyarakat. Hal ini tampak dalam pemberitaan Kompas.com berikut ini:

"Perlu kedisiplinan masyarakat dan ketegasan pemerintah Gabriel menyebut bahwa masyarakat Indonesia butuh sinyal ketegasan dan konsistensi dari pemerintah. "Kombinasi antara ketidaktegasan atau ketidakkonsistenan dengan sikap masyarakat yang acuh atau menganggap remeh membuat respon terhadap Covid-19 dengan kebijakan apapun jadi kurang efektif," jelas Gabriel. Menurut dia, kunci penanganan Covid-19 adalah adanya aksi kolektif antara pemerintah dan masyarakat. " (Kompas.com)"

Berbeda dengan Kompas.com, Tempo.co dalam pemberitaannya samasekali tidak membahas tentang pentingnya perilaku disiplin masyarakat dalam meningkatkan efektitivitas penanganan Covid-19. Tempo.co bahkan tidak menyebutkan bagaimana peran masyarakat seharusnya dalam penanganan pandemi Covid-19. Ini menunjukkan bahwa dalam sudut pandang Tempo.co pemerintahlah yang seharusnya bertanggungjawab dalam menangani pandemic Covid-19.

Uniknya pemerintah yang dimaksud oleh Tempo.co dalam hal ini bukanlah keseluruhan pemerintahan baik pusat maupun daerah, melainkan hanya pemerintah Pusat. Hal ini menunjukkan bagaimana Tempo.co tidak mendukung kebijakan-kebijakan pemerintah pusat khususnya Presiden Jokowi. Presiden Jokowi malah layak diberi kartu merah menurut Tempo.co. Kartu merah dalam permainan sepak bola adalah simbolisasi bahwa pemain telah melakukan pelanggaran dan sebagai konsekuensinya ia harus dicabut haknya untuk bermain. Penggunaan kata kartu merah ini seakan menunjukkan betapa seriusnya kesalahan yang dilakukan oleh pemerintah pusat khususnya presiden dalam penanganan COVID-19 sehingga ia layak diberhentikan.

Selanjutnya, untuk menyelesaikan persoalan kebijakan penanganan Covid-19, Kompas.com dan Tempo.co juga memiliki pandangan yang berbeda. Dalam bingkai Kompas.com, solusi untuk persoalan kebijakan penanganan Covid-19 di Indonesia adalah dengan melakukan perbaikan komunikasi publik dan komunikasi krisis pemerintah. Pemerintah disarankan untuk memastikan bahwa komunikasi ke masyarakat tentang Covid-19 ini sampai secara proporsional, tepat, akurat sehingga tidak ada info yang simpang siur dan keliru. Informasi yang disampaikan terkait Covid-19 juga tidak boleh bias dan menakut-nakuti sehingga orang menjadi paranoid serta stress berlebihan.

Selain perbaikan komunikasi kepada publik, Kompas.com juga menyarankan agar pemerintah membuat kebijakan berdasarkan bukti ilmiah. Kebijakan yang diambil juga hendaknya tidak bertentangan dengan undangundang yang sudah ada. Kompas.com juga menganjurkan agar setiap stakeholder yang terlibat dalam penanganan Covid-19 berkordinasi satu dengan yang lain agar tidak terjadi tumpang-tindih kebijakan. Sementara itu, Tempo.co dalam pemberitannya tidak 
banyak memberikan solusi bagi penanganan Covid-19. Solusi yang disarankan oleh Tempo.co bagi pemerintah pusat adalah evaluasi cara kerja dalam menangani COVID19 dengan sinkronisasi kebijakan dan penyederhanaan birokrasi untuk memutus mata rantai COVID-19.

\section{Simpulan dan Saran}

\subsection{Simpulan}

Berdasarkan analisis dan pembahasan yang telah dilakukan, peneliti menyimpulkan bahwa ada perbedaan frame berita terkait kebijakan penanganan COVID-19 di Kompas.com dan Tempo.co. Perbedaan tersebut tampak dalam hal pendefinisian masalah, penentuan penyebab masalah, evaluasi moral dan rekomendasi penyelesaian masalah:

a. Dalam bingkai Kompas.com, persoalan kebijakan penanganan Covid-19 adalah persoalan buruknya komunikasi Publik dan komunikasi krisis pemerintah. Sedangkan dalam bingkai Tempo.co, persoalan kebijakan Penanganan Covid-19 adalah persoalan kinerja buruk pemerintah. Hal ini terjadi karena perbedaan keberpihakan kedua media. Kompas.com, terkesan lebih netral dalam menilai kinerja pemerintah. Hal ini tampak dalam isi beritanya yang terkesan tidak sepenuhnya menyalahkan kebijakan pemerintah dalam penanganan COVID-19, tetapi lebih kepada memberikan kritikan terhadap pelaksanaannya. Sementara
Tempo.co tampak konsisten tidak berpihak terhadap pemerintah dalam seluruh pemberitaannya. Tempo.co selalu menempatkan kebijakan pemerintah dalam konteks pro dan kontra karena sejak awal sudah Tempo.co sudah menganggap bahwa kinerja Pemerintah buruk tidak saja dalam hal penanganan COVID-19 tetapi juga dalam berbagai hal.

b. Menurut Kompas.com, buruknya komunikasi Publik pemerintah terjadi karena kebingungan pemerintah dalam mengelola komunikasi krisis dan tidak adanya sinkronisasi antar-stakeholder. Selain itu tumpang-tindih kebijakan juga dinilai menjadi salah satu penyebab kebingungan masyarakat dalam memahami kebijakan penanganan Covid-19. Sementara dalam pandangan Tempo.co yang menjadi penyebab masalah adalah tidak adanya evaluasi kebijakan pemerintah sehingga terjadi tumpang tindih kebijakan. Selain itu pemerintah juga dianggak lamban dalam mengendalikan penyebaran virus.

c. Dalam bingkai Kompas.com pemerintah sudah berupaya menerapkan kebijakan yang sama dengan negara-negara lain, namun masih belum tegas dalam pelaksanaannya. Selain itu Kompas.com menilai bahwa kedisiplinan masyararakat juga menentukan efektivitas penanganan COVID-19. Sedangkan menurut 
Tempo.co kinerja pemerintah masih belum memuaskan dan masih banyak penyimpangan.

d. Solusi bagi penanganan Covid-19 menurut Kompas.com adalah perbaikan komunikasi Publik pemerintah. Sedangan solusi yang ditawarkan oleh Tempo.co adalah evaluasi kinerja dan kebijakan pemerintah pusat.

Selain perbedaan frame tersebut, hasil penelitian ini juga menemukan bahwa Kompas.com cenderung mendukung setiap kebijakan pemerintah terkait penanganan COVID-19 di Indonesia sedangkan Tempo.co cenderung kontra dengan kebijakan-kebijakan pemerintah dalam penaganan COVID-19

\subsection{Saran}

Penelitian ini masih memiliki kekurangan dalam banyak hal khususnya dalam pengumpulan data berita yang relevan dengan tujuan riset. Peneliti mengumpulkan data berita dengan pencarian manual (kata kunci) sehingga bisa saja ada data berita yang tidak diambil meskipun mungkin relevan untuk riset ini. Untuk itu peneliti selanjutnya barangkali dapat menggunakan aplikasi yang dapat mengumpulkan data lebih akurat. Selain itu periode berita dalam riset ini terbatas hanya 1 bulan sehingga bisa saja ada berita lanjutan yang tidak diangkat dalam penelitian ini. Untuk itu bagi peneliti selanjutnya barangkali bisa melanjutkan dengan periode yang lebih panjang.
Selaian itu hasil penelitian ini tidak dapat menjelaskan secara lengkap objektivitas pemberitaan di kedua media online ini. Untuk itu bagi peneliti selanjutnya bisa menganalisis objektivitas pemberitaan dengan menggunakan metode analisis isi kuantitatif.

\section{Daftar Pustaka}

\section{Buku \& Jurnal}

Bungin, B . (2008). Konstruksi Sosial Media Massa. Jakarta: Kencana

Bungin, B. (2011). Penelitian Kualitatif. Edisi Kedua. Jakarta: Kencana

Creswell, J. W. (2010). Research design: pendekatan kualitatif, kuantitatif, dan mixed. Yogjakarta: PT Pustaka Pelajar.

Eriyanto.(2015).Analisis Framing: Konstruksi, Ideologi dan Politik. Yogyakarta: Lkis

Karman. (2015). Konstruksi Realitas Sosial sebagai Gerakan Pemikiran: Sebuah Telaah Teoritis Terhadap Konstruksi Realitas Peter L.Berger. Jurnal Penelitian dan Pengembangan Komunikasi dan Informatika Volum 5 No 3 ISSN: 20870132

Kriyantono, R. 2020. Teknik Praktis Riset Komunikasi. Jakarta: Kencana

Luhmann, N. (2000). The Reality of The Mass Media. UK: Polity Press

Martono, N. 2010. Metode Penelitian Kuantitatif. Jakarta. Rajawali

Ningsih, I.N.D.K dan Prastya, N.M. 2020. Bingkai Berita COVID-19 Pada Praktek Jurnalisme Warga Website Pemerintah. Yogyakarta:MBridge Press

Pawito. (2008). Penelitian Komunikasi Kualitatif. Yogyakarta: Lkis

Ronda, A.M. (2018). Tafsir Kontemporer Ilmu Komunikasi. Jakarta: yayasan Kompatibel 
Sapahuma, N.Y. 2015. Realitas Politik dalam Media Massa: Konstruksi Pemberitaan Media Massa Seputar $100 \quad$ Hari Pemerintahan Jokowi-JK. Jurnal Politika, vol.6, no.1

Sobur, A. (2015). Analisis Teks Media. Suatu pengantar untuk analisis Wacana, Analisis Semiotik dan Analisis Framing. Bandung: Remaja Rosdakarya

Wibhisono, I.G.L.A. 2020. Analisis Framing Pemberitaan COVID-19 pada Koran Kompas: Edisi Januari 2020. Jurnal Aspikom Vol. 5, No. 2, July 2020, pp. 219-231 P-ISSN: 2087-0442, E-ISSN: 2548-8309

DOI:http://dx.doi.org/10.24329/aspikom. v5i2.717

\section{Berita Tempo.co dan Kompas}

Adyatama, E. 2020. Jokowi Minta Pengendalian COVID-19 di Pulau Jawa Makin Efektif. Ed. Amirullah. Diakses pada Juni 2020 https://nasional.Tempo.co/read/1341315/j okowi-minta-pengendalian-covid- 19-dipulau-jawa-makin-efektif

Adyatama, E. 2020. Peneliti Eijkman: Indonesia Belum Punya Standar Kurva COVID-19. Ed. Enri Kurniawati. Diakses pada Juni 2020https://nasional.Tempo.co/read/1340 337/peneliti- eijkman-indonesiabelum-punya-standar-kurva-COVID-19

Antara. 2020. Politikus PDIP Minta Pemerintah Dengar Tagar Indonesia Terserah. Ed.Syailendra Persada. Diakses pada Juni 2020 dari https://nasional.Tempo.co/read/1344753/p olitikus-pdip-minta-pemerintah-dengartagar-indonesia-terserah

Nugraheny, D.E. 2020. Survei Roda Tiga Konsultan: 76,7 Persen Responden Mengaku Belum Dapat Bansos. Diakses pada Juni 2020 dari https://nasional.Kompas.com/read/2020/0 5/20/13353191/survei-roda- tiga- konsultan-767- persen- respondenmengaku-belum-dapat- bansos.

Nurita, D. 2020. Kebijakan Kontroversial Jokowi di Tengah Pandemi COVID-19. Ed. Endri Kurniawati. Diakses Juni 2020 dari https://nasional.Tempo.co/read/1346017/k ebijakan- kontroversial-jokowi- ditengah-pandemi-COVID-19

Perbrianto, F. 2020. INDEF: Jokowi dan Menterinya Dapat Rapor Merah Penanganan Corona. Ed. Dewi Rina Cahyani. Diakses pada Juni 2020 dari https://bisnis.Tempo.co/read/1335806/ind ef-jokowi-dan-menterinya-dapat- rapormerah-penanganan-corona

Pranita, E. 2020. Berbagai Respons Rakyat untuk Pemerintah Terkait Penanganan COVID-19.Ed. Gloria Setyvani Putri. Diakses pada juni 2020 dari Kompas.comhttps://www.Kompas.com/sa ins/read/2020/04/02/100200323/berbagairespons-rakyat- untuk- pemerintahterkait-penanganan-covid- 19?page=all.

Purnamasari, D.M. 2020. Pemerintah Diminta Perbaiki Komunikasi Publik Terkait Kebijakan Penanganan Pandemi. Ed: Editor : Kristian Erdianto diakses Juni 2020dari https://nasional.Kompas.com/rea d/2020/05/22/13382211/pemerintahdiminta- perbaiki-komunikasi-publikterkait-kebijakan- penanganan?page=all

Purnamasari, D.M. 2020. Pemerintah Diminta Perbaiki Komunikasi Publik Terkait Kebijakan Penanganan Pandemi. Ed. Kritian Erdianto. Diakses pada Juni 2020 dari

https://nasional.Kompas.com/read/2020/0 5/22/13382211/pemerintah-dimintaperbaiki-komunikasi-publik-terkaitkebijakan-penanganan?page=all.

Riana, F. 2020. Penanganan COVID-19, Putri Gus Dur: Era Milenial, Cara Kolonial. Ed.Anton Aprianto. Diakses Juni 2020 
https://nasional.Tempo.co/read/1343455/p

enanganan-COVID-19-putri- gus-

dur-era-milenial-cara-kolonial

Riana, F. 2020.DPR Kritik Kebijakan Pemerintah Tumpang Tindih Tangani COVID-19. Ed. Endri Kurniawati.

Diakses Juni 2020 dari https://nasional.Tempo.co/read/1336803/d pr-kritik- kebijakan-pemerintahtumpang-tindih-tangani-COVID-19

Yahya, A.C. 2020. Terkait Penanganan Covid- 19, Dubes RI: Jangan Bandingkan Indonesia dengan Negara Lain. Ed. Kritian Erdianto. Diakses Juni 2020 dari https://nasional.Kompas.com/read/2020/0 4/29/06084311/terkait- penangananCOVID-19- dubes-ri-janganbandingkan- indonesiadengan? page $=$ all. 
Halaman ini sengaja dikosongkan untuk kepentingan tata letak

Orasi: Jurnal Dakwah dan Komunikasi | Volume 12, No. 1, Juli 2021 